\title{
Fear of failure dengan ketidakjujuran akademik pada siswa SMA yang menjalankan sistem kredit semester
}

\author{
Najah Hamzah Bauzir ${ }^{1}$ dan Uun Zulfiana ${ }^{2}$
}

\begin{abstract}
The duration of study for Credit Semester System or Sistem Kredit Semester (SKS) students is 2 years at the earliest and 4 years at the longest. This condition can cause students to commit academic dishonesty for fear of failing to get good scores. The purpose of this study was to determine the relationship between fear of failure and academic dishonesty in high school students who run in the SKS format using correlational quantitative research methods. The sampling technique was purposive sampling. The research subjects are high school students who run the SKS for at least 1 year and the numbers are 186 subjects. The data collection method used a modified scale and a combination of the Academic Dishonesty Scale and the Academic Dishonesty Instrument and the Performance Failure Appraisal Inventory (PFAI) scale. The results of the data analysis test using the Pearson product moment method showed that there is no relationship between fear of failure and academic dishonesty in high school students who run the SKS. The correlation coefficient is 0.99 and the significance is $0.178(p>0.05)$.
\end{abstract}

\section{Keywords}

Academic dishonesty, fear of failure, high school students running the SKS

\section{Pendahuluan}

Penyelenggaraan Sistem Kredit Semester (SKS) merupakan suatu upaya inovatif untuk meningkatkan mutu pendidikan pada jenjang pendidikan sekolah dasar dan sekolah menengah di Indonesia. Perlunya disusun model kurikulum tingkat satuan pendidikan dengan menggunakan sistem paket dan model kurikulum tingkat satuan pendidikan dengan menggunakan sistem kredit semester merupakan amanat dari Peraturan Pemerintah Nomor 19 Tahun 2005 Pasal 16 Ayat (5). Berdasarkan Pasal 12 Ayat (1) UndangUndang Nomor 20 tahun 2003, sistem kredit semester merupakan perwujudan dari amanat tentang Sistem Pendidikan Nasional (Badan Standar Nasional Pendidikan, 2010).

Siswa dapat memilih beban belajar dan mata pelajaran yang diikuti pada setiap semester berdasarkan struktur kurikulum yang sesuai dengan bakat, minat, dan kemampuannya atau kecepatan belajarnya. Lama belajar siswa yang menjalankan SKS paling cepat tuntas 2 tahun dan selambat-lambatnya 4 tahun yang tertera pada Permendikbud Nomor 158 Tahun 2014 Pasal 10 ayat (1) dan Pasal 3 ayat (3). SMA/MA dengan kategori mandiri dan bertaraf internasional wajib melaksanakan Sistem Kredit Semester (SKS) menurut Peraturan Pemerintah Nomor 19 Tahun 2005, sedangkan sekolah kategori standar dibolehkan menyelenggarakan SKS. Selama ketentuan tentang SKS tidak bertentangan dengan ketentuan dalam Peraturan Menteri, semua ketentuan tentang SKS pada pendidikan dasar dan pendidikan menengah dalam Peraturan Menteri yang sudah ada sebelum Peraturan Menteri ini berlaku tetap berlaku yang telah tertera berdasarkan Permendikbud Nomor 158 Pasal 16 Tahun 2014.

Sekolah Menengah Atas (SMA) merupakan salah satu tempat pendidikan sebagai sarana untuk mengembangkan kemampuan yang dimiliki siswa baik dalam segi kognitif, afektif, maupun psikomotor melalui proses pembelajaran yang dilakukan di sekolah. Aspek moral dan afektif telah berkembang pada masa remaja dan diharapkan mampu mendukung menyelesaikan tugas-tugasnya. Masa remaja merupakan masa perkembangan dalam aspek kognitif yang sudah mencapai taraf operasi formal menurut Piaget (Santrock, 2007). Oleh karenanya dapat disimpulkan bahwa aktivitas siswa SMA merupakan hasil dari berfikir logis. Berdasarkan penjelasan tersebut maka seorang siswa SMA dianggap sudah mampu bertanggung jawab dalam menyelesaikan berbagai tugas salah satunya yakni tugas di bidang akademik.

Pada umumnya seorang siswa masuk SMA pada umur 15 tahun atau lebih. Siswa SMA mulai memasuki tahap perkembangan remaja muda berdasarkan tahap

\footnotetext{
1,2Universitas Muhammadiyah Malang, Indonesia
}

Korespondensi:

Najah Hamzah Bauzir, Fakultas Psikologi Universitas Muhammadiyah Malang

Email: najahhamzahbwz@gmail.com 
perkembangan (Papalia et al., 2009). Bentuk tujuan siswa SMA yang dimaksud pada tahap ini dapat berupa prestasi yang baik atau lulus dari jenjang SMA agar dapat melanjutkan ke jenjang pendidikan yang lebih tinggi lagi serta mencapai karir yang sukses. Siswa harus menyelesaikan SKS sebagai persyaratan naik semester. Siswa yang mampu menyelesaikan SKS dengan cepat lulus dalam waktu 2 tahun. Sebaliknya, apabila siswa tidak mampu menyelesaikan SKS tepat waktu, maka dia akan menempuh pendidikan tingkat SMA lebih dari 3 tahun. Sistem kredit semester ini tidak ada istilah naik kelas atau tidak naik kelas. Siswa akan dihadapkan pada target kredit seluruh mata pelajaran SKS. Siswa akan melaksanakan ujian semester untuk mengetahui gagal atau tidaknya siswa menjalankan SKS.

Sistem SKS dapat melatih kemandirian siswa dalam menempuh kompetensi dasar yang harus diselesaikan. Sebuah penelitian oleh Nisa \& Suharningsih (2012) yang dilakukan dengan menggunakan teknik purposive sampling pada 116 siswa dengan rincian 58 siswa program percepatan dan 58 siswa program normal. Hasil penelitian menunjukkan bahwa terdapat pengaruh positif dan signifikan penerapan SKS terhadap manajemen diri siswa. Beban belajar dan mata pelajaran dapat ditentukan oleh siswa pada setiap semester sesuai dengan kemampuan, bakat, dan minatnya masing-masing. Siswa merasakan mampu belajar mandiri dengan adanya program SKS dan siswa merasakan bertambah kreatif dan kritis. Siswa juga berharap bisa menyelesaikan masa studinya dengan cepat. Namun, sebesar 42,24\% siswa menyatakan ragu-ragu dengan program SKS yaitu sebanyak 49 siswa menyatakan masih bergantung dengan teman yang lainnya dalam hal belajar.

Penelitian terkait program SKS juga dilakukan oleh Muhlis (2017) pada siswa MTs Negeri Sumber Bungur Pamekasan bahwa siswa selalu ingin memperoleh nilai tinggi sesuai dengan standar minimal persyaratan untuk tetap mendapatkan SKS maksimal pada setiap semesternya. Hasil penelitian tersebut menunjukkan bahwa siswa termotivasi untuk mendapatkan nilai sebaik mungkin agar tidak mengulang nilai rendah pada suatu mata pelajaran. Namun, peneliti tidak menemukan penelitian terkait ketidakjujuran akademik pada siswa dalam mencapai nilai yang baik.

Salah satu permasalahan yang sering muncul dalam konteks pendidikan yaitu ketidakjujuran akademik. Kibler (1993) mendefinisikan ketidakjujuran akademik adalah bentuk kecurangan dan plagiarisme dengan melibatkan siswa dalam memberi atau menerima bantuan yang tidak sah dalam latihan akademis atau menerima uang untuk pekerjaan yang bukan dilakukan oleh mereka sendiri. Ketidakjujuran akademik mencakup perbuatan menyontek, menipu, plagiarisme, dan pencurian ide, baik yang dipublikasikan atau tidak dipublikasikan (Jones, 2011).

Ketidakjujuran akademik merupakan permasalah yang terjadi dari tingkat pendidikan sekolah dasar hingga tingkat perguruan tinggi. Hasil penelitian terkait ketidakjujuran akademik dilakukan oleh Fredrika \& Prasetyawati (2013) pada siswa kelas 6 Sekolah Dasar di Indonesia. Penelitian ini menemukan bahwa ketidakjujuran akademik sudah terjadi pada siswa kelas 6 SD dan berada pada level moderat. Hal ini menunjukkan bahwa jenis perilaku ketidakjujuran akademik yang terbanyak dilakukan siswa kelas $6 \mathrm{SD}$ adalah jenis perilaku kecurangan tradisional seperti dimasa lalu yaitu menjiplak PR siswa lain dan saling mencontek saat ujian. Penelitian terkait ketidakjujuran akademik di SMP juga didukung oleh Jani (2019) bahwa siswa SMP melakukan perilaku ketidakjujuran akademik dengan kategori sangat rendah memiliki persentase sebesar $86.7 \%$ dan siswa yang melakukan ketidakjujuran akademik dengan kategori rendah memiliki persentase sebesar $13.3 \%$. Ungusari (2015) mengatakan bahwa ketidakjujuran akademik terjadi salah satunya pada situasi menghadapi ujian pada siswa SMA. Ungusari (2015) melakukan penelitian terkait data awal melakukan ketidakjujuran akademik yaitu dimulai sejak jenjang pendidikan sekolah dasar sebanyak $18.9 \%$, dimulai sejak Sekolah Menengah Pertama sebanyak $60.8 \%$, dan dimulai sejak Sekolah Menengah Atas sebanyak $20.3 \%$.

Penelitian di atas menunjukkan bahwa aktivitas ketidakjujuran akademik sering terjadi pada siswa sekolah dasar maupun menengah. Penelitian juga menunjukkan mereka yang melakukan ketidakjujuran akademik pada tingkat pendidikan yang lebih rendah akan melakukan perilaku yang sama pada tingkat pendidikan yang lebih tinggi (Miller et al., 2007). Ketidakjujuran akademik biasa dilakukan saat siswa melaksanakan ujian ataupun ulangan harian. Ketidakjujuran akademik dilakukan siswa dalam memenuhi kebutuhan untuk lulus ujian, lulus kursus, mendapatkan nilai yang lebih baik namun ketidakjujuran akademik memiliki konsekuensi jangka panjang. Dalam jangka pendek individu yang melakukan ketidakjujuran akademik akan mendapatkan perasaan puas dengan hasil yang baik namun dalam jangka panjang justru sebaliknya, siswa yang melakukan ketidakjujuran akademik akan mendapatkan konsekuensi negatif yaitu mengalami kesenjangan pengetahuan dalam tahap kehidupan tertentu yang akan menurunkan kepuasan (Błachnio, 2019). Penerapan sistem kurikulum baru dengan menggunakan SKS membuat peneliti ingin mengetahui ketidakjujuran akademik yang dilakukan siswa SMA. Variabel bebas yang digunakan dalam melakukan penelitian ini yaitu fear of failure. Dalam penelitian ini peneliti ingin mengetahui apakah terdapat hubungan antara ketidakjujuran akademik yang dengan fear of failure pada siswa SMA yang menjalankan sistem kredit semester.

Sebuah penelitian oleh Błachnio (2019) terkait ketidakjujuran akademik dengan sampel 631 siswa Polandia. Hasil penelitian menunjukkan bahwa ketidakjujuran akademik berkorelasi negatif dengan self control. Individu yang berkomitmen dengan ketidakjujuran akademik memiliki self control yang rendah dan tidak terasa normal 
dibandingkan dengan individu lainnya. Selain itu, ketidakjujuran akademik berkorelasi negatif dengan kepuasan hidup. Selain itu, individu yang tidak mencapai kesuksesan sosial lebih sering terlibat dalam plagiarisme. Penelitian ini juga menemukan bahwa laki-laki memiliki skor lebih tinggi dibanding dengan perempuan(Błachnio, 2019).

Penelitian Friedman, et,al (2016) menunjukkan bahwa $68.8 \%$ perilaku ketidakjujuran akademik dilakukan secara analog (jenis perilaku kecurangan secara tradisional), sementara hanya $31.2 \%$ melakukan perilaku ketidakjujuran akademik secara digital. Adapun frekuensi jenis ketidakjujuran akademik berdasarkan pavela model theory, $78 \%$ dari kasus yang tertangkap dan diberi hukuman oleh komite disiplin yaitu melakukan menyontek, $17.5 \%$ lainnya adalah kasus plagiarisme, dan $4.5 \%$ memfasilitasi ketidakjujuran siswa lain. Sebanyak 60\% siswa yang tertangkap menyatakan bahwa mereka bertindak seperti tidak bersalah, mereka berkeyakinan bahwa apa yang telah mereka perbuat adalah perilaku yang tidak menyalahi aturan (Friedman, et,al, 2016).

Terdapat tiga mekanisme motivasional yang menjadi faktor ketidakjujuran akademik diantaranya yaitu tujuan siswa, harapan siswa untuk mencapai tujuan-tujuan, dan penilaian siswa dari biaya terkait dengan pencapaian tujuan-tujuan (Murdock \& Anderman, 2006). McCabe (1999) menjabarkan bahwa motivasi umum yang ditemukan dalam melakukan ketidakjujuran akademik yaitu adanya tekanan untuk mendapatkan nilai yang lebih baik, keinginan untuk menjadi unggul, kurangnya persiapan, dan tekanan untuk mendapatkan pekerjaan setelah menyelesaikan studi atau sekolah. Salah satu keberhasilan siswa dalam pendidikan ditunjukkan dengan prestasi akademiknya. Pada kenyataannya ditemukan tuntutan prestasi akademik pada siswa semakin tinggi sementara daya belajarnya biasa-biasa saja. Hal inilah yang menyebabkan tingkat keberhasilan siswa dalam prestasi akademik kurang sebagaimana diharapkan oleh sekolah, orang tua, dan siswa itu sendiri. Keberhasilan siswa dalam pendidikannya juga dipengaruhi oleh motivasi berprestasi yang dimiliki. Motivasi berprestasi sebagai daya dorong yang memungkinkan seseorang berhasil mencapai apa yang diidamkan. Seseorang yang memiliki motivasi berprestasi tinggi cenderung untuk selalu berusaha mencapai apa yang diinginkan walaupun mengalami hambatan dan kesulitan dalam meraihnya.

Komponen motivasi berprestasi yang berkaitan dengan karakteristik individu adalah motif berprestasi. Salah satu motif berprestasi yaitu motive to avoid failure atau fear of failure. Motive to avoid failure adalah menghindari dan mengantisipasi pengaruh negatif dari hasil yang ditimbulkan dari kegagalan, seperti rasa malu, rasa terhina, kehilangan status atau kepercayaan diri.

Penelitian berkaitan dengan fear of failure dilakukan oleh Bahrina (2018) dengan subjek sebanyak 100 mahasiswa Psikologi di suatu universitas di daerah Padang. Hasil dari penelitian tersebut menyatakan bahwa terdapat hubungan yang signifikan antara fear of failure dengan perilaku menyontek pada mahasiswa. Hal tersebut menunjukkan bahwa semakin tinggi fear of failure pada mahasiswa, maka akan semakin tinggi perilaku menyontek pada mahasiswa. Begitu sebaliknya semakin rendah fear of failure pada mahasiswa maka semakin rendah perilaku menyontek pada mahasiswa.

Fakhria (2017) melakukan penelitian mengenai fear of failure. Sampel yang terlibat didalam penelitian tersebut adalah 200 siswa SMA di Semarang. Teknik sampel yang digunakan dalam penelitian ini adalah cluster random sampling. Hasil analisa menunjukkan bahwa terhadap hubungan yang signifikan antara fasilitasi sosial dan ketakutan akan kegagalan dengan motivasi berprestasi pada siswa sekolah menengah atas. Semakin tinggi fear of failure maka semakin rendah motivasi berprestasi siswa, begitu sebaliknya semakin rendah fear of failure yang dimiliki siswa, maka semakin tinggi motivasi berprestasi siswa.

Penelitian lain dilakukan oleh Fatimah (2018) terkait fear of failure dengan sampel 210 mahasiswa aktif yang terdaftar di perguruan tinggi di Jakarta dan pernah melakukan minimal satu perilaku plagiarisme. Teknik sampel pada penelitian ini adalah accidental sampling. Hasil penelitian menunjukkan bahwa terdapat hubungan antara fear of failure dengan intensi plagiarisme. Penelitian ini menunjukkan bahwa terdapat hubungan yang signifikan dimana semakin tinggi fear of failure individu maka semakin tinggi juga intensi untuk melakukan plagiarisme, begitu juga sebaliknya semakin rendah fear of failure individu maka semakin rendah juga intensi untuk melakukan plagiarisme.

Fear of failure juga memiliki pengaruh terhadap prokrastinasi akademik (Akmal et al., 2017). Sampel pada penelitian tersebut terdiri dari 182 mahasiswa yang sedang mengerjakan skripsi dan berkuliah di daerah Jakarta. Penelitian tersebut menggunakan teknik incidental sampling dalam menentukan sampel penelitian. Hasil penelitian tersebut juga menunjukkan bahwa motivasi berprestasi berperan dalam memprediksi prokrastinasi akademik pada mahasiswa yang sedang mengerjakan skripsi. Semakin tinggi fear of failure pada mahasiswa, maka semakin besar kecenderungan untuk menunjukkan perilaku prokrastinasi akademik. Sementara itu, semakin tinggi harapan mahasiswa untuk berhasil dalam mengerjakan skripsi maka mahasiswa akan cenderung menampilkan sedikit prokrastinasi akademik (Akmal et al., 2017).

Berdasarkan rangkaian penjelasan di atas, penelitian ini bertujuan untuk mengetahui hubungan antara fear of failure dengan ketidakjujuran akademik pada siswa sekolah menengah atas (SMA) yang menjalankan sistem kredit semester (SKS). Manfaat teoritis dari penelitian ini adalah dapat memberikan wawasan serta sumbangan referensi bagi pengembangan ilmu pengetahuan dan teori khususnya psikologi pendidikan karena sedikitnya sumber penelitian terbaru yang berkaitan dengan fear of failure dan ketidakjujuran akademik begitu juga dengan fenomena sistem kredit semester. Selain itu, penelitian 
ini diharapkan pula dapat memberikan manfaat praktis bagi siswa yang menjalankan sistem kredit semester dan menjadi masukan bagi sekolah agar siswa berusaha untuk tidak melakukan ketidakjujuran akademik. Berdasarkan latar belakang tersebut, maka rumusan masalah penelitian ini adalah: Apakah terdapat hubungan antara fear of failure dengan ketidakjujuran akademik pada siswa yang menjalankan sistem kredit semester (SKS).

\section{Ketidakjujuran Akademik}

Ketidakjujuran akademik didefinisikan sebagai suatu bentuk pelanggaran aturan dan regulasi yang terjadi pada sebagian besar kalangan di lembaga pendidikan tinggi (Pe Symaco \& Marcelo, 2003). Genereux \& McLeod (1995) mendefinisikan ketidakjujuran akademik sebagai tindakan pelajar untuk mendapatkan hasil yang diinginkan melalui cara yang dilarang atau ilegal. Berbagai jenis ketidakjujuran akademik menurut Pavela (1978) termasuk menggunakan bahan atau informasi selama ujian, memfasilitasi orang lain untuk melakukan jenis ketidakjujuran lainnya, mengenali ide orang lain sebagai karya sendiri tanpa menulis sumbernya, dan tidak berkontribusi pada kerja kelompok. Menurut Iyer \& Eastman (2008) ketidakjujuran akademik meliputi empat hal, yaitu perilaku menyontek, plagiarisme, bantuan dari luar, dan menyontek menggunakan gadget pada saat tes (electronic cheating).

Handayani \& Baridwan (2013) melaporkan bahwa ketidakjujuran akademik didominasi oleh faktor motivasional. Murdock \& Anderman (2006) menyebutkan bahwa terdapat tiga mekanisme motivasional yang menjadi faktor ketidakjujuran akademik diantaranya: (a) tujuan siswa, (b) harapan siswa untuk mencapai tujuan-tujuan, dan (c) penilaian siswa dari biaya terkait dengan pencapaian tujuan-tujuan. McCabe (1999) menjabarkan bahwa motivasi umum yang ditemukan dalam melakukan ketidakjujuran akademik yaitu adanya tekanan untuk mendapatkan nilai yang lebih baik, keinginan untuk menjadi unggul, kurangnya persiapan, dan tekanan untuk mendapatkan pekerjaan setelah menyelesaikan studi atau sekolah. Mahasiswa berprestasi pun melakukan ketidakjujuran akademik (Geddes, 2011). Menurut Masood \& Mazahir (2015) menyatakan bahwa ketidakjujuran akademik dapat memberikan dasar pendidikan yang buruk.

Adapun dimensi-dimensi ketidakjujuran akademik menurut Iyer \& Eastman (2008) yaitu:

1. Menyontek diantaranya siswa membuat catatan yang digunakan saat tes; menyalin jawaban dari siswa lain pada ujian; membantu seseorang menyontek saat ujian; secara manual memberikan jawaban dalam ujian.

2. Plagiarisme diantaranya mencantumkan nama dalam tugas berkelompok namun tidak berpartisipasi penuh dalam pekerjaan; menerima bantuan substansial yang belum pernah terjadi sebelumnya pada suatu tugas; menyalin beberapa kalimat materi dari sumber yang diterbitkan tanpa catatan kaki; pemalsuan dan pabrikasi bibliografi; membeli atau menemukan penelitian dari internet untuk diserahkan sebagai karya sendiri.

3. Bantuan dari luar adalah meminta seseorang memeriksa penelitian sebelum menyerahkannya; tanya seseorang tentang isi ujian dari seseorang yang telah mengerjakan ujian; memberikan informasi tentang isi ujian kepada seseorang yang belum mengikuti ujian; bekerja dengan orang lain di proyek individu; mengunjungi seorang profesor untuk mempengaruhi nilai.

4. Electronic Cheating di antaranya menggunakan ponsel (gadget) untuk mengirim pesan teks dengan tujuan untuk mendapatkan bantuan selama ujian; menggunakan ponsel atau perangkat lain untuk memotret ujian.

Faktor-faktor individual ketidakjujuran akademik menurut McCabe \& Trevino (1997) yaitu:

1. Usia, menjadi salah satu faktor seseorang melakukan ketidakjujuran akademik. Hasil penelitian menyatakan bahwa siswa dengan usia yang lebih muda lebih sering menyontek dibandingkan siswa dengan usia lebih tua.

2. Gender, siswa laki-laki lebih sering melakukan ketidakjujuran akademik daripada siswa perempuan. Hal ini dapat dijelaskan dengan teori sosialisasi peran gender yakni perempuan dalam bersosialisasi lebih mematuhi aturan daripada laki-laki.

3. Academic Achievement, siswa yang memiliki prestasi belajar rendah lebih sering melakukan ketidakjujuran akademik daripada siswa yang memiliki prestasi belajar tinggi. Siswa yang memiliki prestasi belajar rendah berusaha mencapai prestasi akademik yang lebih tinggi dengan cara melakukan ketidakjujuran akademik.

4. Parents' Education, siswa yang mempunyai orang tua dengan latar belakang pendidikan yang tinggi lebih rendah dalam melakukan tindakan ketidakjujuran akademik dibanding dengan siswa yang mempunyai orang tua dengan latar belakang pendidikan yang rendah. Siswa dari latar belakang orang tua dengan pendidikan yang lebih tinggi mungkin lebih siap untuk belajar di perguruan tinggi (melalui sekolah menengah yang lebih baik dan mungkin lingkungan yang lebih mendorong untuk prestasi akademik di rumah) dan memiliki komitmen yang lebih tinggi untuk pendidikan lebih lanjut. Namun faktor ini merupakan faktor yang lemah.

5. Extracurricular Activities, siswa yang banyak terlibat dalam kegiatan ekstrakurikuler lebih banyak melakukan ketidakjujuran akademik. Siswa yang terlibat dalam kegiatan ekstrakurikuler kurang berkomitmen untuk mengejar akademik atau kurang fokus karena terbagi waktu dalam kegiatan belajar. 
Faktor-faktor kontekstual ketidakjujuran akademik menurut McCabe \& Trevino (1997) yaitu:

1. Fraternity/Sorority Membership (keanggotaan perkumpulan). Siswa yang bergabung pada perkumpulan, siswa tersebut akan lebih sering melakukan ketidakjujuran akademik. Pada perkumpulan tersebut sekumpulan siswa saling mengajarkan nilai, norma, dan kemampuankemampuan yang berhubungan dengan mudah hingga sulitnya melakukan ketidakjujuran akademik. Perkumpulan tersebut menyediakan catatan ujian, tugas-tugas, laporan tugas laboratorium, dan tugas akademik lainnya yang mudah untuk dicari atau didapatkan.

2. Peer Behavior (perilaku teman sebaya). Perilaku teman sebaya memiliki pengaruh yang penting terhadap ketidakjujuran akademik. Hubungan tersebut dijelaskan dengan menggunakan teori pembelajaran sosial dari Bandura dan teori asosiasi deferensial dari Edwin Sutherland. Teori-teori tersebut mengemukakan bahwa pola perilaku manusia dipelajari dengan mencontoh pola perilaku individu lain yang memiliki sikap menyimpang berpengaruh terhadap peningkatan sikap individu yang menirunya.

3. Peer Disapproval (penolakan teman sebaya terhadap perilaku ketidakjujuran akademik). Teori pembelajaran sosial oleh Bandura (McCabe \& Trevino, 1997) mengemukakan dalam penelitiannya yang mempertimbangkan pengaruh sikap teman sebaya terhadap perilaku ketidakjujuran akademik. Bowers (McCabe \& Trevino, 1997) menyimpulkan bahwa penolakan teman sebaya adalah "penentu paling penting dari perubahan perilaku ketidakjujuran akademik antara sekolah menengah atas dan perguruan tinggi". Menurut Michaels dan Miethe (McCabe \& Trevino, 1997), "novice deviant" akan mengembangkan sikap positif terhadap perilaku menyimpang melalui pergaulan dengan mereka yang terlibat di dalamnya, mendukungnya, atau memperkuatnya.

4. Peer Reporting (Pelaporan teman sebaya). Teori pencegahan oleh Gibs (McCabe \& Trevino, 1997) mengemukakan bahwa pelanggaran akan terjadi terhalangi jika orang yang melakukan kesalahan merasa bahwa mereka kemungkinan akan ditangkap. Karena ketidakjujuran akademik umumnya lebih mungkin diamati oleh siswa lain daripada oleh fakultas. (McCabe \& Trevino, 1997) berpendapat bahwa persepsi siswa tentang kemungkinan tertangkap tergantung pada apakah mereka percaya bahwa siswa lain akan melaporkan perilaku ketidakjujuran akademik tersebut.

5. Severity of Penalties. Teori pencegahan juga menunjukkan bahwa peningkatan konsekuensi dalam perilaku menyimpang harus mengurangi jumlah individu yang mau mengambil suatu resiko (McCabe
\& Trevino, 1997). Argumennya adalah bahwa jika hukuman cukup berat, konsekuensi potensial dari suatu tindakan mungkin lebih besar daripada potensi ganjarannya. Michaels dan Miethe (McCabe \& Trevino, 1997) telah menunjukkan hal itu. Logika ini berlaku untuk persepsi siswa mengenai beratnya hukuman untuk tindakan ketidakjujuran akademik.

6. Faculty Understanding/Support for Academic Integrity Policies (pengertian fakultas / dukungan untuk kebijakan integritas akademik). Sebagian besar lembaga pendidikan tinggi memiliki kebijakan tentang integritas akademik. Beberapa kebijakan ini, seperti yang ditemukan di lembaga dengan kode kehormatan yang kuat, didistribusikan secara luas dan dipahami oleh anggota komunitas akademik, dan mereka menjadi bagian integral dari budaya kampus. Strategi fakultas individual mengurangi tindakan ketidakjujuran akademik.

\section{Fear of failure}

Menurut Conroy (2002) fear of failure adalah dorongan untuk menghindari kegagalan terutama konsekuensi negatif kegagalan berupa rasa malu, menurunnya konsep diri individu, dan hilangnya pengaruh sosial. Dorongan menghindari kegagalan merupakan konsekuensi negatif dari fear of failure dan merupakan kapasitas individu untuk mengantisipasi rasa malu dan penghinaan (Atkinson, 1993). Menurut Elliot \& Thrash (2004) fear of failure adalah sebuah bentuk penghindaran yang didasarkan pada pencapaian prestasi atau keberhasilan. Peneliti motivasi prestasi klasik, Elliot (Conroy, 2003) mendefinisikan fear of failure sebagai motif (motive to avoid failure). Motive to avoid failure adalah menghindari dan mengantisipasi pengaruh negatif dari hasil yang ditimbulkan dari kegagalan, seperti rasa malu, rasa terhina, kehilangan status atau kepercayaan diri (Capa, et,al, 2008).

Siswa dengan fear of failure lebih cenderung mengambil tujuan pencapaian, menurunnya subjective well being seperti self-esteem, kontrol diri, vitality, dan kepuasan hidup, peningkatan laporan gejala fisik, penurunan motivasi intrinsik, dan penurunan nilai (Conroy, 2001). Bishop, Bauer dan Becker (Conroy, 2001) melaporkan dari $35 \%$ mahasiswa yang datang ke pusat konseling universitas menunjukkan bahwa mereka membutuhkan bantuan dalam menangani fear of failure.

Terdapat banyak alasan untuk peduli dengan fear of failure dan konsekuensinya. Pertama, masalah ini dapat mempengaruhi pekerjaan berbagai profesional, termasuk dokter layanan primer, pendidik kesehatan, konselor, guru, dan pelatih. Selain itu, banyak aspek kehidupan anak-anak dan orang dewasa yang rentan terkena dampak fear of failure (Conroy, 2001).

Pemahaman awal tentang fear of failure dikembangkan dari studi motivasi berprestasi eksperimental (experimental achievement motivation). Kegiatan untuk mengukur motif berprestasi yaitu menggunakan Thematic Apperception 
Test (TAT) yang disusun oleh Morgan dan Murray (Conroy, 2001) dan dinilai pada need achievement. Sistem penilaian awal untuk need achievement ini hanya menyediakan indeks fear of failure tidak langsung (dan tidak dapat diandalkan). Dalam elaborasi teoritis, kunci yang membuka jalan untuk pengukuran yang lebih valid. Atkinson merekonsepsi ulang motivasi berprestasi memiliki dua komponen independen yaitu a tendency to avoid failure dan a tendency to achieve success (atau hope of success). Tendency to avoid failure adalah produk dari motif individu untuk menghindari kegagalan (atau kapasitas untuk mengalami rasa malu jika mengalami kegagalan), kemungkinan gagal, dan kompensasi kegagalan.

Dari perspektif perbedaan individu, fear of failure telah dikonseptualisasikan dengan berbagai cara yaitu sebagai kebutuhan (a need), motif, dan kecenderungan afektif. Awalnya Murray (Conroy, 2001) mendefinisikan avoidance (penghindaran) sebagai need to avoid failure pada subjek laki-laki dibangku kuliah. Peneliti motivasi berprestasi klasik oleh Elliot (Conroy, 2001) melanjutkan pendekatan ini dengan mendefinisikan fear of failure sebagai motif (to avoid failure). Atkinson (Conroy, 2001) memasukkan konseptualisasi berbasis afektif dalam teorinya yaitu dengan mendefinisikan motif untuk menghindari kegagalan sebagai kecenderungan untuk mengalami rasa malu dan malu saat gagal. Secara operasional menggunakan instrumen anxiety test untuk mengukur fear of failure.

Adapun menurut Zeidner (Conroy, 2001) fear of failure disebabkan oleh faktor-faktor berikut: sosialisasi dan pengalaman di awal masa anak-anak, lingkungan pembelajaran, pengalaman belajar, biological constitution, faktor kontekstual dan subjektif. Semua faktor ini kemungkinan besar berperan dalam fear of failure namun akan sangat sulit untuk menyelidiki semuanya secara bersamaan. Pengalaman diawal masa anak-anak adalah salah satu pengaruh teori pertama pada fear of failure, perilaku interpersonal yang umum untuk banyak pengaruh yang disebutkan di atas pada fear of failure, dan perilaku interpersonal memberikan akar dari pendekatan psikodinamik untuk memahami fear of failure. Dengan demikian, penyelidikan saat ini akan berfokus pada persepsi dewasa muda tentang pengalaman interpersonal awal mereka dengan pengakuan bahwa pendekatan ini hanya memberikan pemahaman parsial tentang kepribadian fear of failure (Conroy, 2001).

Adapun aspek-aspek fear of failure menurut (Conroy, 2002) adalah:

1. Ketakutan akan penghinaan dan rasa malu. Individu merasakan kekhawatiran tentang apa yang orang lain pikirkan tentang dirinya berkaitan dengan tidak berusaha dan keraguan orang lain tentang dirinya. Individu merasa kurang berharga dibandingkan saat ia mengalami kesuksesan dan merasa bahwa orang lain benar atas keraguan tentang dirinya saat ia gagal.

2. Ketakutan akan penurunan estimasi diri individu. Individu merasa takut bahwa dirinya tidak cukup berbakat dan menyalahkan kurangnya bakat pada dirinya saat mengalami kegagalan. Individu merasa bahwa tidak cukup sukses dalam menampilkan sesuatu dan tidak mempersiapkan hasilnya.

3. Ketakutan akan ketidakpastian masa depan. Saat merasa gagal individu merasa bahwa rencana masa depannya akan terganggu, berubah, dan terlihat tidak pasti.

4. Ketakutan akan hilangnya pengaruh sosial. Saat merasa gagal individu merasa bahwa orang lain kurang tertarik dengan dirinya, orang-orang tampaknya kurang ingin membantu dirinya, cenderung meninggalkan dirinya, dan merasa nilai pada dirinya berkurang bagi orang lain.

5. Ketakutan akan mengecewakan orang yang penting baginya. Individu merasa orang yang penting baginya merasa kecewa, tidak bahagia, kehilangan kepercayaan, dan marah saat individu mengalami kegagalan.

\section{Ketidakjujuran Akademik dan Fear of Failure pada Siswa SMA yang Menjalankan SKS}

Penyelenggaraan Sistem Kredit Semester (SKS) merupakan suatu upaya inovatif untuk meningkatkan mutu pendidikan pada jenjang pendidikan sekolah dasar dan sekolah menengah di Indonesia. Perlunya disusun model kurikulum tingkat satuan pendidikan dengan menggunakan sistem paket dan model kurikulum tingkat satuan pendidikan dengan menggunakan sistem kredit semester merupakan amanat dari Peraturan pemerintah nomor 19 tahun 2005 Pasal 16 Ayat (5). Sistem Kredit semester telah diterapkan selama 1 tahun lebih oleh SMA X di daerah Sumenep. Sistem Kredit Semester memiliki target lama belajar yaitu 2 tahun bagi siswa yang mampu mencapai target SKS dengan cepat dan selambat-lambatnya 4 tahun. Adanya penerapan sistem kredit semester ini siswa termotivasi untuk mendapatkan nilai sebaik mungkin agar tidak mengalami kegagalan yaitu mengulang nilai rendah pada suatu mata pelajaran (Muhlis, 2017).

Siswa termotivasi untuk mendapatkan nilai akademik yang baik dan tidak perlu melakukan remedial dengan tujuan untuk lulus tepat waktu. Siswa termotivasi untuk mendapatkan nilai yang baik agar tidak mengalami kegagalan. Dorongan menghindari kegagalan merupakan konsekuensi negatif dari fear of failure (takut akan kegagalan) dan merupakan kapasitas individu untuk mengantisipasi rasa malu, penghinaan, kehilangan status atau kepercayaan diri. Menurut Elliot \& Thrash (2004) fear of failure adalah sebuah bentuk penghindaran yang didasarkan pada pencapaian prestasi atau keberhasilan. Namun, dalam langkah mendapatkan nilai akademik yang baik belum tentu dilakukan dengan cara yang jujur. 
Siswa melakukan ketidakjujuran akademik untuk menghindari kegagalan dalam bidang akademik dan menghindari konsekuensi dari kegagalan. Permasalahan ketidakjujuran akademik sering dijumpai dalam konteks pendidikan. Menurut Herdian (2017) data awal siswa melakukan ketidakjujuran akademik yaitu dimulai pada jenjang pendidikan SD sebanyak $18.9 \%$, dimulai pada saat SMP sebanyak $60.8 \%$, dan dimulai pada saat SMA sebanyak 20.3\%. McCabe (1999) menjabarkan bahwa motivasi umum yang ditemukan dalam melakukan ketidakjujuran akademik yaitu adanya tekanan untuk mendapatkan nilai yang lebih baik, keinginan untuk menjadi unggul, kurangnya persiapan dan tekanan untuk mendapatkan pekerjaan setelah menyelesaikan studi atau sekolah.

Adanya cara untuk lulus lebih cepat pada siswa SMA menjadikan motivasi bagi siswa untuk mendapatkan nilai yang baik. Terdapat siswa yang melaluinya dengan melakukan ketidakjujuran akademik untuk mendapatkan nilai yang baik. Ketidakjujuran akademik dilakukan siswa sebagai dorongan untuk menghindari kegagalan dan konsekuensi negatif dari fear of failure

\section{Hipotesis}

Terdapat hubungan yang signifikan antara fear of failure dengan ketidakjujuran akademik pada siswa SMA yang menjalankan sistem kredit semester (SKS).

\section{Metode}

Penelitian yang dilakukan ini menggunakan pendekatan kuantitatif dengan desain penelitian korelasional. Penelitian dengan pendekatan kuantitatif menurut Azwar (2010) yaitu pendekatan yang menekankan analisis pada data-data numeric (angka) yang diolah dengan metode statistika. Desain penelitian korelasional bertujuan untuk mengidentifikasi sejauh mana variasi pada variabel yang berkaitan dengan variabel lain berdasarkan koefisien korelasi sehingga informasi yang diperoleh adalah mengenai taraf hubungan yang terjadi antar variabel, juga bertujuan untuk menjelaskan dan memprediksi suatu kejadian yang berhubungan dengan variabel.

\section{Subjek Penelitian}

Populasi menurut Sugiyono (2011) adalah wilayah yang terdiri atas subjek yang telah ditentukan karakteristiknya oleh peneliti untuk diteliti kemudian ditarik kesimpulannya. Setelah menentukan populasi, peneliti mengerucutkan menjadi sampel. Sampel merupakan bagian dari jumlah populasi tersebut (Sugiyono, 2016). Teknik pengambilan sampel dalam penelitian ini menggunakan teknik purposive sampling yang karakteristiknya sudah ditentukan dan diketahui lebih dahulu berdasarkan ciri dan sifat populasinya (Winarsunu, 2002). Subjek dalam penelitian ini adalah siswa kelas XI dan XII yang pernah mengikuti ujian semester yang sedang menjalankan sistem kredit semester
(SKS). Penelitian ini dilakukan terhadap 186 responden yang menjadi sampel penelitian.

\section{Variabel dan Instrumen Penelitian}

Adapun variabel-variabel yang diteliti adalah:

1. Variabel bebas (independent variable) dalam penelitian ini adalah fear of failure. fear of failure yang dimaksud dalam penelitian ini adalah perasaan takut pada siswa untuk menghindari kegagalan akademik seperti tidak lulus tepat waktu dan mendapatkan nilai tidak baik saat melaksanakan ujian, serta untuk menghindari pengaruh negatif dari kegagalan seperti rasa malu, rasa terhina, kehilangan status, kepercayaan diri, mengecewakan orang yang penting dan ketidakpastian masa depan. fear of failure atau takut akan kegagalan pada penelitian ini mengacu pada lima komponen yaitu: expectacy, value, sensitivy to delay, dan delay (Steel, 2007) Instrumen penelitian menggunakan skala pengukuran Failure Appraisal Inventory (PFAI) yang disusun oleh Conroy (2002) dengan reliabilitas koefisien Cronbach's Alpha sebesar 0.798. Instrumen penelitian ini terdiri dari 25 item yang telah diterjemahkan ke dalam Bahasa Indonesia. Skala pengukuran penelitian ini menggunakan skala likert yang disusun dengan item yang mendukung konsep (favorable) dan item yang tidak mendukung konsep (unfavorable). Jawaban pada setiap item berdasarkan respon yang dirasakan secara jujur yang memiliki empat pilihan jawaban pada item favorable: Sangat Sesuai (SS) dinilai 4, Sesuai (S) dinilai 3, Tidak Sesuai (TS) dinilai 2, dan Sangat Tidak Sesuai (STS) dinilai 1. Sedangkan jawaban pada setiap item unfavorable: Sangat Sesuai (SS) dinilai 1, Sesuai (S) dinilai 2, Tidak Sesuai (TS) dinilai 3, dan Sangat Tidak Sesuai (STS) dinilai 4. Alasan mengadaptasi alat ukur ini adalah item-item yang ingin diteliti sesuai dengan konteks penelitian.

2. Variabel terikat (dependent variable) dalam penelitian ini adalah ketidakjujuran akademik. Ketidakjujuran akademik yang dimaksud dalam penelitian ini adalah siswa yang melakukan perilaku tidak jujur yaitu perilaku menyontek, bantuan dari luar, plagiarisme, dan menyontek menggunakan gadget pada saat tes (electronic cheating) secara sengaja untuk mendapatkan keberhasilan atau mencapai tujuantujuan berkaitan dengan akademik. Ketidakjujuran akademik pada penelitian ini mengacu pada dua komponen yaitu perilaku menyontek dan plagiarisme menurut McCabe \& Trevino (1993), sedangkan menurut Iyer \& Eastman (2008) ketidakjujuran akademik dari perilaku menyontek, plagiarisme, bantuan dari luar, dan menyontek menggunakan gadget pada saat tes (electronic cheating). Instrumen penelitian menggunakan skala dengan modifikasi dan kombinasi antara Academic Dishonesty Scale 
(McCabe \& Trevino, 1993) dan Academic Dishonesty Instrument (Iyer \& Eastman, 2008) oleh Faradiena (2019) sebanyak 20 item dengan reliabilitas koefisien Cronbach's Alpha sebesar 0.89. Peneliti memodifikasi beberapa item agar sesuai dengan kondisi siswa SMA yang menjalankan sistem kredit semester dan menghapus beberapa item yang dianggap sama. Alasan mengadaptasi alat ukur ini adalah item-item yang ingin diteliti sesuai dengan konteks penelitian. Pada item favorable yang memiliki alternatif jawaban (frekuensi): Pernah lebih dari 2x dinilai 4, Pernah $2 \mathrm{x}$ dinilai 3 , Pernah $1 \mathrm{x}$ dinilai 2, dan Tidak pernah dinilai 1. Sedangkan pada item unfavorable yang memiliki alternative jawaban (frekuensi): Pernah lebih dari 2x dinilai 1, Pernah 2x dinilai 2, Pernah $1 \mathrm{x}$ dinilai 3 , dan Tidak pernah dinilai 4.

Hasil uji validitas dan reliabilitas alat ukur ketidakjujuran akademik dan fear of failure dengan jumlah responden 50 siswa SMA yang menjalankan Sistem Kredit Semester diperoleh indeks reliabilitas alat ukur ketidakjujuran akademik yaitu 0.800 dari 13 item dan indeks reliabilitas alat ukur fear of failure yaitu 0.901 dari 24 item. Adapun indeks daya beda aitem alat ukur ketidakjujuran akademik yaitu 0.358-0.578 dan indeks daya beda aitem alat ukur fear of failure yaitu 0.320-0.753.

\section{Prosedur dan Analisis Data}

Prosedur dalam penelitian yang dilakukan terdiri dari tiga prosedur utama sebagai berikut:

1. Tahap persiapan, dimulai dengan mencari fenomena-fenomena yang berkaitan dengan masalah psikologi pendidikan yang berasal dari sumber terpercaya. Kemudian peneliti tertarik dengan ketidakjujuran akademik dan fear of failure sebagai variabel penelitian. Peneliti mengidentifikasi masalah dengan tujuan memberikan batasan permasalahan agar cakupan penelitian fokus pada tujuannya. Peneliti menentukan variabel bebas dan variabel terikat penelitian kemudian penjelasan setiap variabel didukung oleh penelitian terdahulu dan melakukan pendalaman materi melalui kajian teoritik yang relevan dengan topik pembahasan, sehingga dapat dirumuskan hipotesis penelitian. Peneliti mengadaptasi instrumen penelitian dari skala jurnal nasional yaitu modifikasi dan kombinasi antara Academic Dishonesty Scale (McCabe \& Trevino, 1993) dan Academic Dishonesty Instrument (Iyer \& Eastman, 2008) oleh Faradiena (2019) dan peneliti mengadaptasi dari jurnal Internasional Performance Failure Appraisal Inventory (PFAI) yang disusun oleh Conroy (2002). Selanjutnya, peneliti melakukan uji coba atau try out instrumen penelitian kepada responden sebanyak 50 siswa SMA yang menjalankan sistem kredit semester
Tabel 1. Deskripsi Subjek Penelitian

\begin{tabular}{lll}
\hline Kategori & \multicolumn{2}{l}{ Frekuensi Presentase } \\
\hline Kelas & & \\
Kelas XI & 90 & 48.4 \\
Kelas XII & 96 & 51.6 \\
Usia & & \\
15 tahun & 12 & 6.5 \\
16 tahun & 67 & 36 \\
17 tahun & 89 & 47.8 \\
18 tahun & 18 & 9.7 \\
Kategori Ketidakjujuran Akademik & & \\
Rendah & 35 & 18.8 \\
$\quad$ Sedang & 118 & 63.4 \\
Tinggi & 33 & 17.7 \\
Kategori fear of failure & & \\
Rendah & 33 & 17.7 \\
Tinggi & 153 & 82.3 \\
\hline
\end{tabular}

dengan kriteria minimal menjalankan sistem kredit semester 1 tahun. Setelah melakukan uji coba atau try out instrumen penelitian, peneliti menganalisis data menggunakan Statistical Package For Social Sciense (SPSS) 21 sehingga diperoleh validitas dan reliabilitas item instrumen penelitian.

2. Tahap pelaksanaan, peneliti menyebarkan skala berupa google form kepada siswa SMA yang menjalankan sistem kredit semester (SKS) sesuai dengan jumlah sampel yang ditentukan. Peneliti menyebarkan skala kepada SMAN X di Sumenep dan beberapa disebarkan melalui sosial media twitter. Instrumen penelitian yang disebarkan terdiri dari dua skala yaitu, skala fear of failure dan skala ketidakjujuran akademik. Penyebaran instrumen penelitian dilakukan selama 3 bulan yaitu mulai disebarkan dari bulan Oktober hingga Desember 2020.

3. Terakhir, pada tahap analisis yaitu pengumpulan dan pengolahan data dari penyebaran dua skala kepada 186 subjek. Data-data yang diperoleh diolah menggunakan Statistical Package For Social Science (SPSS) 21 yaitu analisis parametrik dengan jenis data interval menggunakan analisis uji korelasi product moment pearson. Selanjutnya penyusunan laporan penelitian ilmiah tertulis dan dapat dipertanggungjawabkan.

\section{Hasil}

Total subjek pada penelitian ini dilakukan terhadap 186 siswa kelas XI dan XII yang menjalankan sistem kredit semester. Pada Tabel 1 dipaparkan deskripsi data siswa yang menjadi sampel penelitian.

Subjek dalam penelitian ini merupakan siswa kelas XI dan XII yang menjalankan sistem kredit semester minimal 1 tahun dengan rentang usia 15-18 tahun dengan kategori terbesar ketidakjujuran akademik yaitu pada kategori 
Tabel 2. Uji Normalitas Variabel Ketidakjujuran Akademik dan fear of failure

\begin{tabular}{llll}
\hline & \multicolumn{3}{l}{ Kolmogorov-Smirnov } \\
& Statistic & df & Sig \\
\hline Ketidakjujuran Akademik & 0.048 & 186 & 0.2 \\
fear of failure & 0.052 & 186 & 0.2 \\
\hline
\end{tabular}

sedang dan fear of failure terbanyak berada pada kategori tinggi.

Hasil uji normalitas dari variabel ketidakjujuran akademik dan fear of failure yaitu data berdistribusi normal dapat dilihat pada Tabel 2. Adapun signifikansi data ketidakjujuran akademik dan fear of failure masingmasing 0.200 sehingga dapat dikatakan normal karena nilai $p>0.05$.

Berdasarkan hasil analisa data yang dipaparkan pada Tabel 3 terlihat bahwa ketidakjujuran akademik pada siswa SMA yang menjalankan SKS mayoritas berada pada kategori sedang dan fear of failure mayoritas berada pada kategori tinggi.

Penelitian ini bertujuan untuk mengetahui ada atau tidaknya hubungan antara ketidakjujuran akademik dan fear of failure dengan melakukan analisis korelasi product moment pearson. Dari hasil analisis didapatkan hasil bahwa tidak ada hubungan antara antara variabel ketidakjujuran akademik dan fear of failure pada siswa SMA yang menjalankan SKS dengan $\mathrm{r}=0.99$ dan nilai signifikansi 0.178 dimana $p>0.05$ yang menyatakan tidak adanya hubungan antara dua variabel.

\section{Diskusi}

Penelitian ini bertujuan untuk mengetahui hubungan antara ketidakjujuran akademik dan fear of failure pada siswa SMA yang menjalankan SKS. Hasil penelitian menunjukkan bahwa tidak adanya hubungan antara ketidakjujuran akademik dan fear of failure pada siswa SMA yang menjalankan SKS. Berdasarkan uji korelasi menunjukkan hasil bahwa hipotesis ditolak sehingga tidak ada hubungan antara ketidakjujuran akademik dan fear of failure. Adapun menurut McCabe \& Trevino (1997) penelitian menemukan bahwa terdapat hubungan antara ketidakjujuran akademik dan academic achievement. Siswa yang memiliki prestasi belajar rendah lebih sering melakukan ketidakjujuran akademik daripada siswa yang memiliki prestasi belajar tinggi. Siswa yang memiliki prestasi belajar rendah berusaha mencapai prestasi akademik yang lebih tinggi dengan cara melakukan ketidakjujuran akademik. Sedangkan, siswa yang telah lolos pada SMA dengan akreditasi A mayoritas melakukan ketidakjujuran akademik pada kategori sedang. Hal ini menunjukkan bahwa siswa yang telah terseleksi untuk melanjutkan pendidikan yang lebih tinggi pada sekolah favorit juga melakukan ketidakjujuran akademik meski tidak pada kategori yang tinggi.
Selanjutnya, hasil analisis pada penelitian ini mendapati bahwa mayoritas siswa yang menjadi subjek penelitian ini berada pada kategori sedang dalam melakukan ketidakjujuran akademik dan pada kategori tinggi dalam merasakan fear of failure. Adapun siswa yang wajib untuk menjalankan SKS yaitu siswa yang menempuh pendidikan SMA/MA dengan kategori mandiri dan bertaraf internasional, sedangkan sekolah kategori standar diperbolehkan menyelenggarakan SKS. Keputusan tersebut menerangkan bahwa sekolah kategori mandiri (SKM) "harus" menerapkan SKS, sedangkan sekolah kategori standar menerapkan sistem paket dan "dapat" menerapkan SKS. Menurut Departemen Pendidikan Nasional (2008) bahwa Sekolah Kategori Mandiri (SKM) yaitu sekolah terakreditasi A. Siswa yang lolos seleksi pada sekolah terakredtasi A merupakan siswa yang telah tersaring dengan berbagai tes kemampuan. Namun, pada penelitian ini tidak menjelaskan tes kemampuan apa saja yang menjadi persyaratan lolosnya siswa untuk menempuh jenjang pendidikan SMA/MASederajat yang telah terakreditasi A.

Hal ini dapat dikatakan bahwa siswa cukup siap untuk menjalankan sistem kredit semester. Pernyataan tersebut dapat dibuktikan dengan mayoritas siswa yang menjadi subjek penelitian ini berada pada kategori sedang dalam melakukan ketidakjujuran akademik saat menjalankan sistem kredit semester yang artinya siswa sekali-kali melakukan ketidakjujuran akademik. Menurut McCabe \& Trevino (1993) sebagian besar kecurangan yang dilakukan oleh siswa didorong oleh tekanan untuk mencapai keberhasilan. Siswa melakukan ketidakjujuran akademik karena adanya kebutuhan untuk memenuhi harapan keluarga, lulus sekolah, dan prospek kerja. Beberapa siswa bahkan membenarkan melakukan ketidakjujuran akademik mereka dengan memperhatikan perlunya mempertahankan IPK minimum untuk mempertahankan bantuan keuangan (beasiswa) mereka. Siswa merasa takut akan kegagalan sehingga siswa melakukan ketidakjujuran akademik.

Hasil penelitian menunjukkan bahwa siswa berada pada kategori tinggi dalam merasakan fear of failure. Adapun siswa yang menghadapi Ujian Nasional (UN) juga mengalami kecemasan karena takut gagal dalam menyelesaikan Ujian Nasional (Pangastuti, 2014). Siswa yang akan menghadapi UN mendapatkan tekanan internal maupun eksternal. Tekanan tersebut dapat datang melalui tekanan dari orang tua, sekolah ataupun lingkungan yang menuntut siswa untuk lulus UN. Tekanan tersebut juga dapat muncul dari dalam diri mereka sendiri atau disebut tekanan internal. Tekanan internal yang dialami oleh siswa dalam menghadapi UN yaitu rasa malu, takut diremehkan oleh masyarakat atau lingkungan bila tidak lulus UN. Adanya tuntutan tersebut yang dapat menimbulkan kecemasan pada siswa yaitu diantaranya takut gagal menghadapi UN, merasa cemas hingga tidak memiliki selera makan akibat dari takut gagal menghadapi UN. Siswa yang menghadapi UN merasa masa depannya ditentukan oleh hasil UN. Hal tersebut serupa dengan siswa SMA yang menjalankan sistem kredit semester. 
Tabel 3. Kategorisasi Ketidakjujuran Akademik dan fear of failure

\begin{tabular}{lllllllll}
\hline \multirow{2}{*}{ Variabel } & \multirow{2}{*}{ Rata-rata } & SD & \multicolumn{2}{l}{ Kategori } & & & & \\
\cline { 3 - 8 } & & & & Tinggi & & Sedang & & \multicolumn{2}{c}{ Rendah } \\
\cline { 3 - 8 } & & & Frekuensi & Persentase & Frekuensi & Persentase & Frekuensi & Persentase \\
\hline Ketidakjujuran Akademik & 32 & 7 & 33 & 17.7 & 118 & 63.4 & 35 & 18.8 \\
Fear of Failure & 69 & 11 & 153 & 82.3 & - & - & 33 & 17.7 \\
\hline
\end{tabular}

Siswa merasakan takut gagal (fear of failure) tidak dapat menempuh SKS sebagai syarat kelulusan. Perasaan tersebut diperoleh dari tekanan untuk selalu mendapatkan standar SKS. Siswa yang dapat menempuh minimal 22 SKS dapat menempuh pendidikan hanya 2 tahun di SMA. Sedangkan, siswa yang tidak dapat memenuhi minimal SKS akan menempuh pendidikan di SMA selama 3 tahun atau 4 tahun.

Menurut Sujana (Indah \& Shofiah, 2012) seseorang melakukan ketidakjujuran akademik karena menghindari penguat negatif di lingkungan sekolah, (2) menghindari ketakutan terhadap kegagalan, kecemasan, atau ketegangan yang dialami, dan (3) berada pada kondisi terjepit. Penelitian yang dilakukan oleh Indah \& Shofiah (2012) menyatakan $18.06 \%$ mahasiswa berada pada kategori rendah dalam melakukan ketidakjujuran akademik. Sebesar $67.74 \%$ mahasiswa berada pada kategori sedang dalam melakukan ketidakjujuran akademik artinya mahasiswa kadang-kadang melakukan ketidakjujuran akademik dalam menyelesaikan tugas atau pembelajaran di kampus seperti menyalin pekerjaan mahasiswa lain dengan izin atau tanpa izin, sekali-kali menggunakan catatan kecil, membantu teman berlaku curang saat ujian atau tes dan menyalin materi menjadi tugas milik pribadi. Sebesar $14.19 \%$ berada pada kategori ketidakjujuran akademik yang tinggi artinya mahasiswa selalu memprioritaskan melakukan ketidakjujuran akademik untuk menyelesaikan tugas perkuliahan atau tuntutan akademik di kampus. Arifah et al. (2018) dalam penelitiannya menemukan bahwa ketidakjujuran akademik yang dilakukan siswa dipengaruhi oleh tekanan akademik sebesar $22.1 \%$ dan locus of control sebesar $14.7 \%$. Terdapat $54.63 \%$ mahasiswa yang melakukan ketidakjujuran akademik dengan kategori sangat rendah sehingga dapat diambil kesimpulan mahasiswa jarang melakukan ketidakjujuran akademik (Arifah et al., 2018)

Baran \& Jonason (2020) melakukan penelitian terhadap mahasiswa sarjana di Polandia sebanyak 390 mahasiswa. Peneliti melakukan penelitian peran psychopathy, achievement goals, dan efikasi diri pada ketidakjujuran akademik. Peneliti menemukan bahwa aspek disinhibition dari psychopathy dan orientasi mastery goal memprediksi frekuensi ketidakjujuran akademik siswa. Orientasi mastery goal memediasi hubungan antara aspek disinhibition dan meanness dari psychopathy dan ketidakjujuran akademik. Koscielniak \& Bojanowska (2019) melakukan penelitian terhadap 219 mahasiswa Polandia. Hasil menunjukkan bahwa terdapat hubungan beberapa nilai (prestasi dan keamanan) dengan ketidakjujuran akademik secara signifikan dimoderasi oleh kinerja (nilai) akademik siswa.

Lestari \& Lestari (2017) selain konformitas kelompok, Alapare dan Onakoya (Lestari \& Lestari, 2017) menyebutkan bahwa harga diri juga mempengaruhi perilaku ketidakjujuran akademik. Iyer dan Eastman (Lestari \& Lestari, 2017) mengemukakan bahwa mahasiswa yang secara umum memiliki harga diri yang rendah biasanya lebih sering terlibat dalam melakukan ketidakjujuran akademik. Maka diketahui bahwa konformitas kelompok, harga diri, dan efikasi diri mempengaruhi ketidakjujuran akademik. Harga diri, konformitas kelompok, dan efikasi diri mempengaruhi ketidakjujuran akademik sebesar $39.7 \%$, sedangkan $60.3 \%$ dipengaruhi oleh variabel lain yang tidak diteliti dalam penelitiannya. Adapun konformitas kelompok mempengaruhi sebesar 31.3\% ketidakjujuran akademik, efikasi diri mempengaruhi $7.1 \%$ ketidakjujuran akademik, dan harga diri mempengaruhi $1.3 \%$ ketidakjujuran akademik.

Penelitian yang dilakukan oleh Pantu et al. (2020) menemukan bahwa tekanan teman sebaya berpengaruh secara signifikan dan positif terhadap ketidakjujuran akademik. Hal ini menunjukkan bahwa individu yang melakukan ketidakjujuran akademik ketika mendapatkan tekanan dari teman sebayanya. Adapun adanya pengaruh tekanan teman sebaya terhadap ketidakjujuran akademik dapat dijelaskan melalui faktor kognitif dan faktor sosial. Individu melakukan ketidakjujuran akademik karena faktor konformitas dan penolakan sosial sebagai penjelasan dari faktor sosial. Harapan untuk berhasil dalam ujian merupakan faktor kognitif yang melatarbelakangi individu melakukan ketidakjujuran akademik.

Ketidakjujuran akademik juga memiliki hubungan positif yang signifikan dengan tekanan orang tua terhadap siswa. Responden penelitian ini terdiri dari 600 siswa dengan usia 14-18 tahun yang berdomisili di DKI Jakarta. Semakin tinggi tekanan orang tua yang diperoleh oleh siswa maka semakin tinggi pula ketidakjujuran akademik yang dilakukan oleh siswa. Hasil penelitian ini menunjukkan bahwa ketidakjujuran akademik dan perfeksionisme pada siswa berhubungan positif. Semakin perfeksionis siswa maka akan semakin tinggi perilaku ketidakjujuran akademik (Lusiane \& Garvin, 2018). McCabe \& Trevino (1997) menyebutkan beberapa alasan mengapa siswa terlibat dalam ketidakjujuran akademik, salah satunya yaitu karena mereka mendapat tekanan untuk mendapatkan nilai yang tinggi. 
Menurut Uyun (2020) psikologi berperan penting dalam penerimaan siswa baru untuk melanjutkan ke pendidikan yang lebih tinggi. Saat siswa akan menempuh pendidikan pada jenjang SMA, psikolog mengkategorikan kecerdasan (intelegensi umum), kepribadian, minat dan bakat pada siswa. Tujuan dari pemberian tes psikologi adalah sebagai acuan dalam memilih jurusan yang berdasarkan pada minat atau bakat dan kemampuan umum pada suatu mata pelajaran. Serangkaian tes yang telah dievaluasi oleh psikolog ini dapat menentukan apakah siswa dapat lolos atau tidak untuk ke SMA/MA favorit pilihannya. Kemudian, psikologi berperan membantu memahami pola kebiasaan siswa yang teridentifikasi melalui beberapa tes. Hasil dari tes tersebut dapat terlihat bagaimana reaksi calon siswa saat menghadapi suatu masalah pada lingkup pertemanan atau pembelajaran. Setelah itu, psikologi juga berperan penting untuk mengidentifikasi kemampuan dan potensi calon siswa. Selain untuk mengukur kemampuan dan potensi calon siswa, yaitu dapat mengukur bakat dan minat masing-masing siswa. Hal ini dapat menjadi acuan pemilihan jurusan pada siswa SMA yang dapat ditentukan melalui tes minat dan bakat.

Kiswanto (2017) melakukan penelitian tentang karakteristik rasa takut gagal pada young entrepreneurial berdasarkan minat karir mahasiswa. Penelitian memberikan kontribusi bahwa entrepreneur muda lebih memahami gambaran kegagalan yang akan diraih dari pada gambaran kesuksesan yaitu nilai kecil, tidak lulus, drop out (DO), rasa malu, penghargaan diri rendah, tidak percaya diri, kehilangan dukungan, bangkrut/kehilangan uang, sulit membayar hutang. Kejelasan gambaran tersebut memberikan hambatan para entrepreneur muda untuk merealisasikan impiannya dalam bidang entrepreneurship yang kemudian membentuk rasa takut akan kegagalan. Mahasiswa menjadi takut untuk melangkah, malu akan apa yang dilakukannya, penghargaan diripun rendah. Pemahaman rasa takut akan kegagalan akan memahami bagaimana mengembangkan motivasi mahasiswa, resiliensi dan tujuan hidupnya.

Takut gagal juga dirasakan oleh mahasiswa yang sedang menempuh skripsi. Mahasiswa tersebut takut gagal dalam menyelesaikan skripsi dengan tuntutan lulus tepat waktu dan berbagai macam permasalahan ataupun tekanan yang dicapai sehingga timbul ketakutan akan kegagalan jika tidak memenuhi tuntutan atau harapan tersebut (Wahyuni \& Irsalina, 2014). Nainggolan (Wahyuni \& Irsalina, 2014) dalam penelitiannya ditemukan adanya rasa takut gagal pada diri mahasiswa. Ketakutan akan kegagalan tersebut timbul dari tuntutan dan harapan yang tinggi terhadap kesuksesan akademik. Ketakutan akan kegagalan tersebut merupakan penghindaran dari konsekuensi yang akan didapatkan jika gagal seperti merasa malu yang dirasakan oleh mahasiswa. Hal tersebut serupa juga dengan siswa SMA yang menjalankan sistem kredit semester. Siswa mendapatkan tuntutan dan harapan untuk kesuksesan akademiknya. Sebesar $72.0 \%$ dari 186 siswa merasakan fear of failure pada kategori tinggi. Hal ini membuktikan bahwa siswa ataupun mahasiswa akan mengalami takut akan kegagalan apabila mendapatkan tuntutan dan memenuhi harapan agar tidak mengalami kegagalan dan menerima konsekuensi dari kegagalan tersebut (Wahyuni \& Irsalina, 2014).

Hidayah (2012) menyatakan mahasiswa merasa gagal apabila gagal dalam mencapai puncak prestasi atau gagal lulus. Sebanyak 63\% mengalami kecemasan karena takut mendapatkan penghinaan dan rasa malu. Mahasiswa merasa takut apabila orang lain memandang rendah karena kegagalan mereka di bidang pendidikan. Sebanyak $93.93 \%$ mahasiswa mengalami penurunan estimasi diri (self estimate) dengan berpendapat bahwa mereka merasa kurang cukup pintar dalam mengikuti proses pembelajaran di bangku kuliah. Sebanyak 54.54\% menunjukkan bahwa mereka merasa takut hilangnya pengaruh sosial apabila gagal. Mahasiswa juga takut akan ketidakpastian masa depan sebesar $84.84 \%$ mereka berpendapat bahwa kegagalan dapat merusak rencana kehidupan di masa depan. Mahasiswa juga takut mengecewakan orang yang penting bagi mereka sebesar $81.81 \%$ apabila mereka gagal dalam pencapaian akademik. Adapun ketakutan akan kegagalan pada mahasiswa yang diteliti tergolong pada kategori tinggi sebesar $52.63 \%$ dan sisanya dengan persentase $47.37 \%$ tergolong pada kategori rendah. Hartono (Hidayah, 2012) berpendapat bahwa semakin tinggi harapan atau tuntutan dari orangtua maka akan menimbulkan rasa takut, panik, dan putus asa yang dialami pada anak. Anak tidak berani melakukan tugas-tugasnya diakibatkan takut jika mengalami kegagalan sehingga membuat orang tuanya kecewa, marah, dan kehilangan kasih sayang. Sehingga berakibat anak mengalami kehilangan keinginannya sendiri diakibatkan ingin selalu memenuhi harapan dari orangtua. Adapun harapan tersebut berasal dari harapan orang tua dengan tujuan agar anak mencapai keberhasilan dalam bidang akademik.

Putri (2019) melakukan penelitian untuk mengetahui tingkat rasa takut akan kegagalan saat menghadapi kompetisi olahraga mahasiswa pendidikan jasmani dan strategi yang mereka gunakan untuk mengatasi rasa takut itu sendiri. Adapun strategi diterapkan yaitu teknik relaksasi, berpikir positif, dan fokus pada pertandingan hal tersebut dapat dipengaruhi karena mereka telah terbiasa menghadapi pertandingan. Dalam hal ini, relaksasi dan berpikir positif tentunya terkait dengan upaya untuk meredakan kecemasan yang dapat mengatasi rasa takut akan kegagalan yang dihadapi. Terkait dengan fokus terhadap pertandingan menunjukkan bahwa goal-setting dan goal-directed self-talk memiliki pengaruh terhadap penanganan perilaku, prediksi positif, dan teknik yang tepat untuk menurunkan rasa takut akan kegagalan.

Adapun keterbatasan dalam penelitian ini yaitu subjek yang digunakan masih terlalu umum, lebih baik kriteria subjek yang digunakan dibedakan setiap kelasnya. Adapun kurun waktu setiap sekolah yang telah menjalankan sistem kredit semester tidak sama pada setiap sekolah sehingga 
persiapan siswa dalam menghadapi sistem kredit semester juga berbeda.

\section{Kesimpulan}

Berdasarkan hasil yang diperoleh dalam penelitian ini, maka peneliti mengambil kesimpulan bahwa tidak terdapat hubungan antara ketidakjujuran akademik dengan fear of failure pada siswa SMA yang menjalankan Sistem Kredit Semester dengan koefisien korelasi sebesar 0.99 dan signifikansi sebesar $0.178 \quad(p>0.05)$. Hal ini menunjukkan bahwa tinggi rendahnya ketidakjujuran akademik tidak dapat menjelaskan tinggi rendahnya fear of failure terhadap siswa SMA yang menjalankan SKS dan fear of failure (takut gagal) bukanlah satusatunya variabel yang menjelaskan munculnya perilaku ketidakjujuran akademik. Terdapat beberapa faktor lain yang mempengaruhi ketidakjujuran akademik seperti harga diri, academic achievement, tekanan teman sebaya, dan tekanan orang tua.

Bagi siswa diharapkan mempersiapkan segala macam kebutuhan agar tidak gagal dalam menjalani sistem kredit semester. Diharapkan sekolah juga peduli dengan perilaku yang ketidakjujuran akademik yang dilakukan oleh siswa dan memberikan pengertian kepada siswa untuk tidak melakukan ketidakjujuran akademik karena individu yang melakukan ketidakjujuran akademik akan mendapatkan konsekuensi negatif dalam waktu jangka panjang.

Bagi peneliti selanjutnya yang ingin meneliti hubungan ketidakjujuran akademik dan fear of failure diharapkan dapat melibatkan lebih banyak responden yang menjadi sampel penelitian karena keterbatasan pada penelitian ini yaitu menggunakan sampel yang terbatas sehingga jumlah sampel secara luas masih perlu ditingkatkan. Selain itu peneliti juga menganjurkan kepada peneliti selanjutnya untuk menghubungkan ketidakjujuran akademik dengan fear of failure dengan faktor-faktor lainnya seperti harga diri, academic achievement, dan tekanan teman sebaya. Peneliti selanjutnya dapat mengganti variabel fear of failure dengan variabel estimasi diri atau ketidakpastian masa depan terhadap ketidakjujuran akademik.

\section{Referensi}

Akmal, S. Z., Arlinkasari, F., \& Fitriani, A. U. (2017). Hope of success and fear of failure predicting academic procrastination students who working on a thesis. Guidena: Jurnal Ilmu Pendidikan, Psikologi, Bimbingan dan Konseling, 7(1), 7886. http://dx.doi.org/10.24127/gdn.v7i1.724

Arifah, W., Setiyani, R., \& Arief, S. (2018). Pengaruh Prokrastinasi, Tekanan Akademik, Religiusitas, Locus Of Control Terhadap Perilaku Ketidakjujuran Akademik Mahasiswa Pendidikan Akuntansi UNNES. Economic Education Analysis Journal, 7(1), 106-119. https://journal. unnes.ac.id/sju/index.php/eeaj/article/view/22860

Atkinson, R.L. (1993). Pengantar psikologi. Jakarta: Erlangga.
Azwar, S. (2010). Metode penelitian psikologi. Yogyakarta: Pustaka Pelajar.

Bahrina, R. (2018). Hubungan antara fear of failure dengan menyontek pada mahasiswa. Jurnal Riset Psikologi, 2018(3). http://dx.doi.org/10.24036/jrp.v2018i3.3984

Baran, L., \& Jonason, P. K. (2020). Academic dishonesty among university students: The roles of the psychopathy, motivation, and self-efficacy. Plos one, 15(8), e0238141. https://doi.org/ 10.1371/journal.pone. 0238141

Błachnio, A. (2019). Don't cheat, be happy. Self-control, selfbeliefs, and satisfaction with life in academic honesty: A cross-sectional study in Poland. Scandinavian Journal of Psychology, 60(3), 261-266. https://doi.org/10.1111/sjop. 12534

Badan Standar Nasional Pendidikan. (2010). Paradigma Pendidikan Nasional Abad XXI. [Online]. Tersedia: Http://www.bsnp-indonesia.org/id/wp-content/uploads/ 2012/04/laporan-bsnp-2010.Pdf. Diakses pada tanggal 10 Desember 2019.

Capa, R. L., Audiffren, M., \& Ragot, S. (2008). The effects of achievement motivation, task difficulty, and goal difficulty on physiological, behavioral, and subjective effort. Psychophysiology, 45(5), 859-868. https://doi.org/10.1111/j. 1469-8986.2008.00675.x

Conroy, D. E. (2001). fear of failure: An exemplar for social development research in sport. Quest, 53(2), 165-183. https: //doi.org/10.1080/00336297.2001.10491736

Conroy, D. E. (2002). The performance failure appraisal inventory: User's manual (2nd edition). Human Kinetics Publishers. Inc.

Conroy, D. E., Willow, J. P., \& Metzler, J. N. (2002). Multidimensional fear of failure measurement: The performance failure appraisal inventory. Journal of Applied Sport Psychology, 14(2), 76-90. https://doi.org/10.1080/10413200252907752

Conroy, D. E. (2003). Representational models associated with fear of failure in adolescents and young adults. Journal of Personality, 71(5), 757-784. https://doi.org/10.1111/14676494.7105003

Departemen Pendidikan Nasional(2008). Kurikulum tingkat satuan pendidikan. Jakarta: Depdiknas.

Elliot, A. J., \& Thrash, T. M. (2004). The intergenerational transmission of fear of failure. Personality and Social Psychology Bulletin, 30(8), 957-971. https://doi.org/10.1177/ 0146167203262024

Fakhria, M., \& Setiowati, E. A. (2017). Motivasi berprestasi siswa ditinjau dari fasilitasi sosial dan ketakutan akan kegagalan. Psikohumaniora: Jurnal Penelitian Psikologi, 2(1), 29-42. DOI https://10.21580/pjpp.v2i1.1279

Faradiena, F. (2019). Uji Validitas Alat Ukur Ketidakjujuran Akademik. JP3I (Jurnal Pengukuran Psikologi dan Pendidikan Indonesia), 8(2), 88-104. DOI: http://dx.doi.org/10. 15408/jp3i.v8i2.13316

Fatimah, D. G. (2018). Ketakutan akan kegagalan dan intensi plagiarisme pada mahasiswa. Jurnal Psikologi Ulayat: Indonesian Journal of Indigenous Psychology, 5(1), 45-59. 
https://doi.org/10.24854/jpu70

Fredrika, M. E., \& Prasetyawati, W. (2013). Gambaran kecurangan akademik pada siswa kelas 6 sekolah dasar (Unpublished undergraduate thesis). Universitas Indonesia, Jakarta.

Friedman, A., Blau, I., \& Eshet-Alkalai, Y. (2016). Cheating and feeling honest: Committing and punishing analog versus digital academic dishonesty behaviors in higher education. Interdisciplinary Journal of e-Skills and Life Long Learning, 12, 193-205. Retrieved from http://www.informingscience. org/Publications/3629

Geddes, K. A. (2011). Academic dishonesty among gifted and high-achieving students. Gifted Child Today, 34(2), 50-56. https://doi.org/10.1177/107621751103400214

Genereux, R. L., \& McLeod, B. A. (1995). Circumstances surrounding cheating: A questionnaire study of college students. Research in Higher Education, 36(6), 687-704. https://doi.org/10.1007/BF02208251

Handayani, Y., \& Baridwan. (2013). Faktor faktor yang mempengaruhi perilaku ketidakjujuran akademik: Modifikasi theory of planned behaviour (TPB). Jurnal Ilmiah Mahasiswa FEB, 2(1).

Herdian, H. (2017). Ketidakjujuran Akademik Pada Saat UNBK Tahun 2017. Jurnal Psikologi Jambi, 2(2), 1-9. https://doi. org/10.22437/jpj.v2i2.4790

Hidayah, D. N. (2012). Persepsi mahasiswa tentang harapan orang tua terhadap pendidikan dan ketakutan akan kegagalan. Educational Psychology Journal, 1(1), 62-67. http://journal. unnes.ac.id/sju/index.php/epj

Indah, P. S., \& Shofiah, V. (2012). Hubungan prokrastinasi akademik dengan ketidakjujuran akademik pada mahasiswa psikologi UIN Suska Riau. Jurnal Psikologi, 8(1), 29-36. http://dx.doi.org/10.24014/jp.v8i1.181

Iyer, R., \& Eastman, J. K. (2008). The impact of unethical reasoning on academic dishonesty: Exploring the moderating effect of social desirability. Marketing Education Review, 18(2), 21-33. https://doi.org/10.1080/10528008.2008.11489034

Jani,U. K. (2019). Hubungan antara religiusitas dengan perilaku menyontek pada siswa sekolah menengah pertama (Unpublished undergraduate thesis). Universitas Islam Indonesia, Yogyakarta.

Jones, D. L. (2011). Academic dishonesty: Are more students cheating?. Business Communication Quarterly, 74(2), 141150. https://doi.org/10.1177/1080569911404059

Kibler, W. L. (1993). Academic dishonesty: A student development dilemma. Naspa Journal, 30(4), 252-267. https: //doi.org/10.1080/00220973.1993.11072323

Kiswanto, A. (2017). Karakteristik rasa takut gagal (fear of failure) pada young entrepreneurial berdasarkan minat karier mahasiswa. Jurnal Fokus Konseling, 3(1), 47-56. https://doi. org/10.26638/jfk.288.2099

Koscielniak, M., \& Bojanowska, A. (2019). The role of personal values and student achievement in academic dishonesty. Frontiers in Psychology, 10, 1887. https://doi.org10.3389/ fpsyg.2019.01887
Lestari, S. P., \& Lestari, S. (2017). Konformitas kelompok, harga diri dan efikasi diri sebagai prediktor perilaku ketidakjujuran akademik pada siswa. Jurnal Penelitian Humaniora, 18(1), 54-64. https://doi.org/10.23917/humaniora.v18i1.3641

Lusiane, L., \& Garvin. (2018). Tekanan Orangtua, Perfeksionisme, dan Ketidakjujuran Akademik pada Pelajar di Jakarta. Jurnal Ilmiah Psikologi MIND SET, 9(1), 60-77. https://doi. org/10.35814/mindset.v9i01.726

Masood, A., \& Mazahir, M. S. (2015). Personality traits and selfcontrol as predictors of motivational correlates of academic dishonesty. Danish Journal of Psychology Sciences, 2, 70-78. 10.6084/M9.FIGSHARE.1510923.V1

McCabe, D. L., \& Trevino, L. K. (1993). Academic dishonesty: Honor codes and other contextual influences. The journal of higher education, 64(5), 522-538. https://doi.org/10.1080/ 00221546.1993 .11778446

McCabe, D. L., \& Trevino, L. K. (1997). Individual and contextual influences on academic dishonesty: A multicampus investigation. Research in Higher Education, 38(3), 379-396. https://doi.org/10.1023/A:1024954224675

McCabe D. L. (1999). Academic dishonesty among high school students. Adolescence, 34(136), 681-687.

McCabe, D. L., Trevino, L. K., \& Butterfield, K. D. (1999). Academic integrity in honor code and non-honor code environments: A qualitative investigation. The Journal of Higher Education, 70(2), 211-234. https://doi.org/10.1080/ 00221546.1999 .11780762

Miller, A. D., Murdock, T. B., Anderman, E. M. \& Poindexter, A. L.. (2007). Who are all these cheaters? Characteristics of academically dishonest students. In E. M. Anderman, \& T. B. Murdock (Eds.), Psychology of Academic Cheating(pp. 9-32). San Diego, CA: Academic Press.

Muhlis, A. (2017). Pengembangan Pembelajaran dengan Sistem Kredit Semester di MTS Negeri Sumber Bungur Pamekasan. NUANSA: Jurnal Penelitian Ilmu Sosial dan Keagamaan Islam, 14(1), 139-184. https://doi.org/10.19105/ nuansa.v14i1.1317

Murdock, T. B., \& Anderman, E. M. (2006). Motivational perspectives on student cheating: Toward an integrated model of academic dishonesty. Educational Psychologist, 41(3), 129-145. https://doi.org/10.1207/s15326985ep4103_1

Nisa, A. Z., \& Suharningsih. (2012). Pengaruh penerapan Sistem Kredit Semester (SKS) terhadap manajemen diri siswa di SMPN 1 Sedati Sidoarjo. Jurnal Pendidikan Kewarganegaraan, 3(4), 1423-1439.

Pangastuti, M. (2014). Efektifitas pelatihan berpikir positif untuk menurunkan kecemasan dalam menghadapi ujian nasional (UN) pada siswa SMA. Persona: Jurnal Psikologi Indonesia, 3(1), 32-41. https://doi.org/10.30996/persona.v3i01.367

Pantu, E. A., Karmiyati, D., \& Winarsunu, T. (2020). Pengaruh tekanan teman sebaya dan kecemasan menghadapi ujian terhadap ketidakjujuran akademik pada mahasiswa. Jurnal Ilmiah Psikologi Terapan, 8(1), 54-65. https://doi.org/10. 22219/jipt.v8i1.9127. 
Papalia, D. E., Olds, S. W., \& Feldman, R. D. (2009). Human development perkembangan manusia. Jakarta: Salemba Humanika.

Pavela, G. (1978). Judicial review of academic decisionmaking after horowitz. NOLPE School Law Journal, 8(1), 55-75.

Pe Symaco, L., \& Marcelo, E. (2003). Faculty perception on student academic honesty. College Student Journal, 37(3), 327+. https://link.gale.com/apps/doc/A108836897/AONE? $\mathrm{u}=$ anon $\sim$ be $1 \mathrm{c} 2 \mathrm{eb} 7 \&$ sid $=$ googleScholar $\& \mathrm{xid}=46 \mathrm{~d} 5 \mathrm{~d} 86 \mathrm{~b}$

Putri, W. (2019). Ketakutan akan kegagalan mahasiswa pendidikan jasmani dalam menghadapi kompetisi. Journal of Teaching Physical Education in Elementary School, 2(2), 129-133. https://doi.org/10.17509/tegar.v2i2.18106

Santrock, J.W. (2007). Perkembangan anak (Edisi ketujuh, Jilid dua). Jakarta : PT. Erlangga.

Steel, P. (2007). The nature of procrastination: a meta-analytic and theoretical review of quintessential self-regulatory failure. Psychological bulletin, 133(1), 65-94. https://doi.org/ 10.1037/0033-2909.133.1.65

Sugiyono. (2011). Metode penelitian kuantitatif, kualitatif, dan $R \& D$. Bandung: Alfabeta.
Sugiyono. (2016). Metode penelitian kuantitatif, kualitatif, dan $R \& D$. Bandung: Alfabeta.

Ungusari, E. (2015). Kejujuran dan ketidakjujuran akademik pada siswa SMA yang berbasis agama [Undergraduate thesis, Universitas Muhammadiyah Surakarta]. http://eprints.ums.ac.id/36940/

Uyun, M. (2020). Peran psikolog dalam bidang pendidikan, pemerintahan dan industri. Psympathic: Jurnal Ilmiah Psikologi, 7(1), 61-78. https://doi.org/10.15575/psy.v7i1. 6349

Wahyuni, L. D., \& Irsalina, F. I. (2014). Komunikasi interpersonal terhadap dosen pembimbing dan ketakutan akan kegagalan mahasiswa dalam menyelesaikan skripsi. JPPP-Jurnal Penelitian dan Pengukuran Psikologi, 3(2), 85-93. https:// doi.org/10.21009/JPPP.032.07

Winarsunu, T. (2002).Statistik dalam penelitian psikologi dan pendidikan. UMM Press. 